MEDIA ILMIAH TEKNIK SIPIL

\title{
PENGARUH PENAMBAHAN ZAT ADITIF FOSROC CONPLAST R DAN FOSROC SP 337 TERHADAP KUAT TEKAN BETON DENGAN VARIASI KADAR AIR
}

\section{EFFECT OF FOSROC CONPLAST R AND FOSROC SP 337 ADDITIVES ON THE COMPRESSIVE STRENGTH OF CONCRETE WITH VARIATION OF WATER-CEMENT RATIO}

\author{
Syafri Wardi ${ }^{* 1}$, Aulia Kartika Sridewi ${ }^{2}$, Arman A. ${ }^{3}$ \\ ${ }^{1,3}$ Dosen, Program Studi Teknik Sipil Sarjana, Institut Teknologi Padang \\ ${ }^{2}$ Alumni, Program Studi Teknik Sipil Sarjana, Institut Teknologi Padang \\ Korespondensi: wardi.syafri@itp.ac.id
}

\begin{abstract}
ABSTRAK
Fosroc Conplast R dan Fosroc SP 337 adalah zat aditif untuk campuran beton yang digunakan untuk memperlambat pengerasan campuran beton sehingga dapat memperpanjang waktu pemasangan beton. Penelitian-penelitian terdahulu telah membuktikan bahwa penambahan zat aditif Fosroc SP 337 dan/atau Fosroc Conplast $\mathrm{R}$ meningkatkan kuat tekan beton, namun belum ada penelitian yang menyelidiki pengaruh penambahan zat aditif tersebut terhadap kuat tekan beton dengan variasi kadar air. Maka penelitian ini dilakukan untuk mengetahui pengaruh penambahan zat aditif Fosroc Conplast R dan Fosroc SP 337 terhadap kuat tekan beton dengan variasi kadar air, dengan melakukan pengujian material untuk merancang campuran beton, kemudian dilakukan uji kuat tekan beton dan nilai kuat tekan beton dibandingkan dengan kuat tekan rencana berdasarkan SNI 03-2834-2000. Kuat tekan beton yang diperoleh pada umur 7 dan 28 hari. Beton dengan penambahan zat aditif Fosroc Conplast R 1\% dan Fosroc SP 337 1\% menghasilkan kuat tekan beton yang lebih tinggi dari kuat tekan rencana berdasarkan SNI 03-2834-2000 untuk beton normal tanpa campuran zat aditif, sehingga zat aditif ini aman digunakan untuk memperpanjang waktu pengecoran beton di lapangan.
\end{abstract}

Kata Kunci: faktor air semen, Fosroc Conplast R, Fosroc SP 337, zat aditif

\begin{abstract}
Fosroc Conplast $R$ and Fosroc SP 337 are additives for the concrete mixture which are used to delay the setting time of the concrete mixture, thus, it can extend the time for the concreting work. Previous studies have verified that the addition of Fosroc SP 337 and/or Fosroc Complast $R$ additives increases the compressive strength of concrete, but no previous studies have investigated the effect of adding these additives on the compressive strength of concrete with variations in water-cement ratio. Therefore, this research is conducted to investigate the effect of adding Fosroc Conplast $R$ and Fosroc SP 337 additives on the compressive strength of concrete with variations in water-cement ratio, by conducting the test on properties of the materials for designing the concrete mixture proportion, then the compressive strength test is conducted and the compressive strength of concrete is compared with the design compressive strength based on SNI 03-2834-2000. The compressive strength test was conducted at the concrete age of 7 and 28. Concrete with the addition of 1\% Fosroc Conplast $R$ and 1\% Fosroc SP 337 additives, produces a higher compressive
\end{abstract}


Pengaruh Penambahan Zat Aditif..., Syafri Wardi ${ }^{(1)}$, Aulia Kartika Sridewi ${ }^{(2)}$, Arman A. ${ }^{(3)}$

strength than the design strength of normal concrete without additives, thus, this additive is applicable to extend the time for the concreting work in the construction field.

Keywords: additives, Fosroc Conplast R, Fosroc SP 337, water cement ratio

\section{PENDAHULUAN}

Beton merupakan salah satu pilihan sebagai bahan struktur dalam konstruksi bangunan. Beton diminati karena banyak memiliki kelebihan-kelebihan dibandingkan dengan bahan lainnya, antara lain harganya yang relatif murah, mempunyai kekuatan yang baik, bahan baku penyusun mudah didapat, tahan lama, tahan terhadap api, tidak mengalami pembusukan. Inovasi teknologi beton selalu dituntut guna menjawab tantangan akan kebutuhan, beton yang dihasilkan diharapkan mempunyai kwalitas tinggi meliputi kekuatan dan daya tahan tanpa mengabaikan nilai ekonomis. Sifat fisis material sangat mempengaruhi mutu dan spesifikasi beton tersebut. (Arman A., dkk, 2017).

Fosroc Conplast R dan Fosroc SP 337 adalah zat aditif untuk campuran beton yang digunakan untuk memperlambat pengerasan campuran beton sehingga dapat memperpanjang waktu pemasangan beton. Penelitian sebelumnya oleh Arman A., dkk. (2017) telah menyelidiki pengaruh setting time pada campuran beton yang menggunakan Fosroc Conplast SP 337 dan Conplast R. Kesimpulan yang diperoleh dari hasil pengujian adalah lama pengadukan (setting time) yang paling baik untuk campuran beton dengan tambahan zat aditif Conplast Sp 337 dan Conplast $\mathrm{R}$ sebanyak $1 \%$ adalah 30 menit, yang menghasilkan beton kuat tekan rata-rata (fc') 44.63 $\mathrm{MPa}$.

Dari penelitian yang dilakukan oleh Asri dan Nisumanti (2014) tentang kuat tekan beton mutu tinggi dengan penambahan Consplast SP337, didapatkan hasil bahwa beton yang dibuat dengan campuran 1:2:3 dengan penambahan SP 337 dapat mencapai fc' sebesar $46.61 \mathrm{MPa}$, kuat tekan rata-rata beton dengan campuran 1,$2 ; 2 ; 3$ dengan penambahan SP 337 mencapai fcr' $=48,81 \mathrm{MPa}$, dan kuat tekan rata-rata beton dengan campuran 1 : 2,5 : 3 dengan penambahan SP 337 hanya mencapai $\mathrm{fcr}^{\prime}=35,67 \mathrm{MPa}$. Dari hasil tersebut, terlihat bahwa faktor komposisi jumlah pemakaian semen sangat menentukan kekuatan beton, dan penambahan Conplast Superplasticixer SP 337 sangat membantu dalam pengerjaan dan sangat besar pengaruhnya terhadap kepadatan beton.

Berdasarkan penelitian oleh Aulia, dkk (2015) tentang pengaruh penggunaan agregat halus daur ulang dan agregat kasar daur ulang dari limbah beton padat, didapat hasil bahwa campuran beton menggunakan $20 \%$ agregat halus daur ulang yang sesuai dengan standar ASTM C-33 dan dengan menggunakan admixture Conplast SP 337, dapat menghasilkan beton dengan kuat tekan rata-rata sebedar 31,67 $\mathrm{MPa}$. Mutu beton ini serta lebih tinggi dari beton yang tidak menggunakan agregat daur ulang dan tanpa Consplast SP 337 yang hanya memiliki kuat tekan sebesar 30,11 MPa.

Penelitian oleh Arman dan Ramayanti (2018) yang melaksanakan uji esperimental pembuatan beton instan dengan penambahan zat aditif Fosroc SP 337 dan Conplast R, didapatkan hasil bahwa beton instan dengan campuran Fosroc SP 337 dan Conplast $\mathrm{R}$ memiliki kuat tekan rata-rata sebesar 33,83 $\mathrm{MPa}$, lebih tinggi daripada beton normal tanpa campuran zat aditif Fosroc SP 337 dan Conplast $\mathrm{R}$ yang hanya memiliki kuat tekan rata-rat sebesar 23,65 $\mathrm{MPa}$.

Penelitian terdahulu tersebut di atas, menunjukkan bahwa penambahan zat aditif Fosroc SP 337 dan/atau Fosroc Complast R menghasilkan kuat tekan beton yang lebih tinggi dibandingkan beton tanpa tambahan zat aditif tersebut. Namun, belum ada penelitian yang menyelidiki pengaruh penambahan zat aditif Fosroc Complast $\mathrm{R}$ dan Fosroc SP 337 terhadap kuat tekan beton dengan variasi kadar air. Penelitian ini dilakukan untuk melihat bagaimana pengaruh penambahan zat aditif Fosroc Complast R dan Fosroc SP 337 terhadap campuran beton dengan variasi kadar air, yang mana kedua zat aditif tersebut digunakan untuk memperlambat pengerasan campuran beton sehingga dapat memperpanjang waktu pengecoran beton di lapangan. 


\section{TINJAUAN PUSTAKA}

\section{Beton}

Beton adalah campuran antara semen Portland atau semen hidraulik lainnya, agregat halus, agregat kasar, dan air, dengan atau tanpa bahan tambahan yang membentuk masa padat. Beton disusun dari agregat kasar dan agregat halus. Agregat halus yang digunakan biasanya adalah pasir alam maupun pasir yang dihasilkan oleh industri pemecah batu, sedangkan agregat kasar yang dipakai biasanya berupa batu alam maupun batuan yang dihasilkan oleh industri pemecah batu.

\section{Zat Aditif Fosroc Conplast R}

Fosroc Conplast $\mathrm{R}$ adalah salah satu jenis bahan tambah (aditif) pada beton untuk meningkatkan kinerja beton. Fosroc Conplast R adalah campuran pereduksi air bebas klorida berdasarkan bahan hidroksikarboksilat yang dipilih. Ini disediakan sebagai larutan berwarna coklat yang langsung larut dalam air. Conplast $R$ memungkinkan kadar air beton untuk bekerja lebih efektif. Hidrasi awal semen juga tertunda, sehingga terjadi keterlambatan waktu pengerasan beton (https://fosroc.com).

Kegunaan Fosroc Conplast $\mathrm{R}$ pada campiran beton adalah:

- Meningkatkan efektivitas kadar air campuran beton.

- Untuk memperpanjang waktu pemasangan beton, memperpanjang waktu pengerjaan waktu dan meminimalkan masalah penundaan.

- Memperpanjang umur kerja screed beton semi-kering

- Sangat cocok untuk digunakan pada campuran yang memiliki abu layang dan juga meningkatkan kehidupan kerja campuran beton semi kering, Khususnya jenis RCC (Roller Compacted Concrete) campuran.

Keuntungan penggunaan Fosroc Conplast $\mathrm{R}$ pada campuran beton adalah:

- Pengurangan air secara signifikan meningkatkan tekan kekuatan di segala usia dan meningkatkan daya tahan melalui produksi beton permeabilitas rendah.

- Retardasi terkontrol memperpanjang masa kerja dan pengerasan waktu untuk kemudahan konstruksi.
- Kontrol pengerasan meningkatkan pembentukan selip dan membantu mencegah pembentukan sendi dingin dalam jumlah besar.

- Memungkinkan tingkat kekuatan yang ditentukan dipenuhi dengan pengurangan kandungan semen atau peningkatan kemampuan kerja.

- Bebas klorida, aman digunakan pada prategang dan penguat beton.

\section{Zat Aditif Fosroc SP 337}

Berdasarkan brosur Fosroc, Conplast SP337 baik untuk meningkatkan kekuatan atau untuk menghasilkan beton kemampuan kerja tinggi atau mengurangi kandungan semen beton atau untuk memperlambat waktu pengerasan beton. (https://fosroc.com)

Kegunaan penggunaan Fosroc SP 337 pada campuran beton adalah:

- Menghasilkan beton workability tinggi tanpa kehilangan kekuatan.

- Untuk mempromosikan kekuatan awal dan akhir yang tinggi dengan memanfaatkan pengurangan air sementara menjaga kemampuan kerja.

- Menghasilkan beton berkualitas tinggi dengan daya tahan yang lebih baik dan kedap air.

- Pada dosis yang lebih tinggi, keuntungan dapat diambil dari keterlambatan waktu pengaturan awal beton khususnya dalam jumlah besar.

Keuntungan pengunaan Fosroc SP 337 pada campuran beton adalah:

- Peningkatan kemampuan kerja membuat lebih mudah dan penempatan yang lebih cepat serta pemadatan yang optimal.

- Memberikan kekuatan yang lebih tinggi tanpa peningkatan kadar semen atau pengurangan kemungkinan untuk dilaksanakan. Mengurangi kecepatan kehilangan kemampuan kerja biasanya terkait dengan superplasticiser.

- Mengurangi retak susut karena rasio air semen yang lebih rendah. Membuat air beton kedap air.

- Memperbaiki ketahanan dan impermeabilitas beton.

- Aman pada beton prategang produksi. 


\section{METODE}

Penelitian ini bersifat eksperimen yang dilaksanakan di laboratorium Teknik Sipil Institut Teknologi Padang (ITP). Penelitian diawali dengan pengujian agregat halus dan agregat kasar. Agregat halus yang digunakan adalah pasir dan agregat kasar yang digunakan adalah split). Pengujian sifat fisik yang dilakukan pada agregat, yaitu:

1. Pemeriksaan gradasi agregat (agregat halus dan kasar)

2. Pemeriksaan kotoran organic (agregat halus)

3. Pemeriksaan passing no.200 (agregat halus \& kasar)

4. Pemeriksaan berat isi agregat (agregat halus \& kasar)

5. Pemeriksaan berat jenis dan penyerapan agregat (agregat halus dan kasar)

6. Pemriksaan keausan agregat (agregat kasar)

Kemudian, rancangan campuran beton (mix Design) direncanakan berdasarkan metoda SNI 03-2834-2000. Setelah merancang campuran beton, maka dilakukan pembuatan benda uji untuk pengujian kuat tekan.

Benda uji dibuat dengan cetakan silinder $150 \mathrm{~mm} \times 300 \mathrm{~mm}$. sebanyak tiga (3) benda uji tiap variasi campuran yang berbeda, seperti diperlihatkan pada tabel 1 .

Tabel 1. Jumlah Benda Uji

\begin{tabular}{lc}
\hline \multicolumn{1}{c}{ Variasi Campuran Beton } & Jumlah \\
\hline $\begin{array}{l}\text { Beton dengan kadar air 0,5 } \\
\text { Beton dengan kadar air 0,4 dan tambahan } \\
\text { zat aditif Fosroc Conplast R 1\% dan Fosroc }\end{array}$ & 3 \\
SP 337 1\% & \\
Beton dengan kadar air 0,5 dan tambahan & \\
zat aditif Fosroc Conplast R 1\% dan Fosroc & 3 \\
SP 337 1\% & \\
Beton dengan kadar air 0,6 dan tambahan \\
zat aditif Fosroc Conplast R 1\% dan Fosroc \\
SP 337 1\%
\end{tabular}

Pada saat umur beton mencapai 7 hari dan pada umur rencana beton 28 hari), dilakukan pengujian kuat tekan beton dengan Universal Testing Machine (UTM). Analisis data dilakukan berdasarkan data hasil uji kuat tekan yang diperoleh.

\section{HASIL DAN PEMBAHASAN}

\section{Pemeriksaan Sifat Fisik Agregat Halus}

Hasil pemeriksanaan agregat halus menunjukkan bahwa material yang digunakan memenuhi spesifikasi gradasi tergolong pada zona II (pasir kasar) dengan modulus kehalusan $(\mathrm{fm})=$ 3,7. Nilai ini menuhi standar AASTHO T 27.

Dari hasil pemeriksaan kadar kotoran organic, didapakan hasil warna sama dengan warna nomor 2 pada tintometer. Hasil ini menjunjukkan kadar organik dalam batas normal (berdasarkan SNI-03-2816-1992).

Hasil uji saringan menunjukkan persentase bahan yang terdapat pada agregat halus yang lolos saringan nomor 200 sebanyak 3,998\%. Berarti agregat halus memiliki kandungan lumpur dibawah batas maksimum 5\% (SNI 03-4142-1996).

Dari hasil pengujian berat isi, diperoleh nilai berat isi sebesar $1,37 \mathrm{gr} / \mathrm{cm}^{3}$. Nilai ini telah sesuai dengan standar minimal berdasarkan SNI 03-4804-1998, yaitu 1,2 gr/ $/ \mathrm{cm}^{3}$.

Hasil pengujian berat jenis agregat halus, menunjukkan nilai berat jenis kering sebesar 2,33 $\mathrm{gr} / \mathrm{cm}^{3}$ dan penyerapan air $4,17 \%$ Nilai ini sesuai dengan SNI 1970:2008 dengan standar berat jenis minimal $2,3 \mathrm{gr} / \mathrm{cm}^{3}$ dan penyerapan air maksimal $5 \%$.

\section{Pemeriksaan Sifat Fisik Agregat Kasar}

Hasil pemeriksaan agregat kasarm menunjukkan nilai fine modulus agregat kasar sebesar 5,95 dan material memenuhi spesifikasi gradasi sesuai standar berdasarkan SNI 03-1968-1990.

Dari hasil uji saringan, diperoleh persentase bahan pada agregat kasar yang lolos saringan No. 200 sebesar 0,98\%. Ini berarti agregat kasar memiliki kandungan lumpur yang memenuhi spesifikasi yaitu dibawah batas maksimum $1 \%$ (SNI 03-4142-1996).

Hasil pengujian berat isi, diperoleh berat isi sebesar $1,64 \mathrm{gr} / \mathrm{cm} 3$. Nilai ini telah sesuai dengan standar minimal berdasarkan SNI 03-4804-1998, yaitu $1,2 \mathrm{gr} / \mathrm{cm} 3$.

Dari data hasil pengujian diperoleh bahwa agregat kasar memiliki BJ (berat jenis) 2,3 gr/ $\mathrm{cm}^{3}$. 
Nilai ini telah memenuhi standar minimal berdasarkan SNI 1969:2008, yaitu 2,3 gr/ $\mathrm{cm}^{3}$.

Hasil pemeriksaan keausan agregat kasar menggunakan mesin los angeles, menunjukkan nilai keausan sebesar $26,10 \%$. Nilai keausan agregat ini telah memenuhi standar berdasarkan PB-0206-76, yaitu maksimal 27\% - 30\%.

\section{Rancangan Campuran Beton (Mix Design)}

Setelah dilakukan pengujian material dasar pembentuk beton, dihitung perencanaan campuran beton. Pada penelitian ini, rancangan campuran beton dibuat berdasarkan metoda SNI 03-2834-2000.

Dari hasil perencanaan campuran beton, maka diperoleh hasil akhir untuk komposisi campuran beton $/ \mathrm{m}^{3}$ untuk benda uji tanpa penambahan zat aditif, yang diperlihatkan pada Tabel 2, 3, dan 4 .

Tabel 2. Komposisi campuran beton normal dengan kadar air 0,4 untuk setiap $\mathrm{m}^{3}$

\begin{tabular}{llll}
\hline No. & $\begin{array}{l}\text { Komposisi } \\
\text { bahan } / \mathbf{M}^{\mathbf{3}}\end{array}$ & Berat & Satuan \\
\hline 1 & Semen & 525 & $\mathrm{~kg}$ \\
2 & Air & 257,86 & $\mathrm{~kg}$ \\
3 & Pasir & 507,56 & $\mathrm{~kg}$ \\
4 & Koral & 1084,82 & $\mathrm{~kg}$ \\
\hline
\end{tabular}

Tabel 3. Komposisi campuran beton normal dengan kadar air 0,5 untuk setiap $\mathrm{m}^{3}$

\begin{tabular}{llll}
\hline No. & $\begin{array}{l}\text { Komposisi } \\
\text { bahan } / \mathbf{M}^{\mathbf{3}}\end{array}$ & Berat & Satuan \\
\hline 1 & Semen & 420 & $\mathrm{~kg}$ \\
2 & Air & 250,52 & $\mathrm{~kg}$ \\
3 & Pasir & 573,54 & $\mathrm{~kg}$ \\
4 & Koral & 1084,82 & $\mathrm{~kg}$ \\
\hline
\end{tabular}

Tabel 4. Komposisi campuran beton normal dengan kadar air 0,6 untuk setiap $\mathrm{m}^{3}$

\begin{tabular}{llll}
\hline No. & $\begin{array}{l}\text { Komposisi } \\
\text { bahan } / \mathbf{M}^{\mathbf{3}}\end{array}$ & Berat & Satuan \\
\hline 1 & Semen & 350 & $\mathrm{~kg}$ \\
2 & Air & 264,02 & $\mathrm{~kg}$ \\
3 & Pasir & 614,07 & $\mathrm{~kg}$ \\
4 & Koral & 1111,90 & $\mathrm{~kg}$ \\
\hline
\end{tabular}

Untuk komposisi campuran beton $/ \mathrm{m}^{3}$ untuk benda uji dengan penambahan zat aditif Fosroc Conplast R dan Fosroc SP 337, dihitung berdasarkan persentase zat aditif terhadap berat air, kemudian dibagi dengan berat jenis zat aditif. Hasil perencanaan komposisi campuran beton $/ \mathrm{m}^{3}$ untuk benda uji dengan penambahan zat aditif Fosroc $\begin{array}{lllllll}\text { Conplast } & \mathrm{R} & 1 \% & \text { dan Fosroc } & \text { SP } & 337 & 1 \%\end{array}$ diperlihatkan pada Tabel 5, 6, dan 7.

Tabel 5. Komposisi campuran beton kadar air 0,4 dengan penambahan Zat Aditif Fosroc Conplast $\mathrm{R}$

$1 \%$ dan Fosroc SP $3371 \%$ untuk setiap $\mathrm{m}^{3}$

\begin{tabular}{llll}
\hline No. & $\begin{array}{l}\text { Komposisi } \\
\text { bahan } / \mathbf{M}^{\mathbf{3}}\end{array}$ & Berat & Satuan \\
\hline 1 & Semen & 525 & $\mathrm{~kg}$ \\
2 & Air & 257,86 & $\mathrm{~kg}$ \\
3 & Pasir & 507,56 & $\mathrm{~kg}$ \\
4 & Koral & 1049,58 & $\mathrm{~kg}$ \\
5 & Fosroc Conplast & 2503,47 & $\mathrm{gr}$ \\
& R 1\% & & \\
6 & Fosroc SP 337 2203,91 & $\mathrm{gr}$ \\
& $1 \%$. & & \\
\hline
\end{tabular}

Tabel 6. Komposisi campuran beton kadar air 0,5 dengan penambahan Zat Aditif Fosroc Conplast R $1 \%$ dan Fosroc SP $3371 \%$ untuk setiap $\mathrm{m}^{3}$

\begin{tabular}{llll}
\hline No. & $\begin{array}{l}\text { Komposisi } \\
\text { bahan } / \mathbf{M}^{\mathbf{3}}\end{array}$ & Berat & Satuan \\
\hline 1 & Semen & 420 & $\mathrm{~kg}$ \\
2 & Air & 261,60 & $\mathrm{~kg}$ \\
3 & Pasir & 573,54 & $\mathrm{~kg}$ \\
4 & Koral & 1084,67 & $\mathrm{~kg}$ \\
5 & Fosroc Conplast & 2539,76 & $\mathrm{gr}$ \\
& R 1\% & & \\
6 & Fosroc SP 337 2235,86 & $\mathrm{gr}$ \\
& $1 \%$ S & & \\
\hline
\end{tabular}

Tabel 7. Komposisi campuran beton kadar air 0,6 debfab penambahan Zat Aditif Fosroc Conplast R

$1 \%$ dan Fosroc SP $3371 \%$ untuk setiap $\mathrm{m}^{3}$

\begin{tabular}{llll}
\hline No. & $\begin{array}{l}\text { Komposisi } \\
\text { bahan } / \mathbf{M}^{\mathbf{3}}\end{array}$ & Berat & Satuan \\
\hline 1 & Semen & 350 & $\mathrm{~kg}$ \\
2 & Air & 264,02 & $\mathrm{~kg}$ \\
3 & Pasir & 614,07 & $\mathrm{~kg}$ \\
4 & Koral & 1111,90 & $\mathrm{~kg}$ \\
5 & Fosroc Conplast & 2563,34 & $\mathrm{gr}$ \\
& R 1\% & & \\
6 & Fosroc SP 337 2256,61 & $\mathrm{gr}$ \\
& $1 \%$ S & & \\
\hline
\end{tabular}

\section{Pembuatan Benda Uji dan Tes Slump}

Setelah rancangan campuran beton selesai di buat, maka dilakukan pembuatan benda uji berdasarkan rancangan campuran tersebut. Hasil pengujian slump dan berat jenis $(\gamma)$ beton dipetlihatkan pada Tabel 8 . 
Tabel 8. Hasil pengujian beton dan nilai slump

\begin{tabular}{llll}
\hline No. & Benda Uji & $\begin{array}{l}\text { Nilai } \\
\text { slump } \\
(\mathbf{c m})\end{array}$ & $\begin{array}{l}\text { tes } \\
\boldsymbol{\gamma} \text { beton } \\
\left(\mathbf{k g} / \mathbf{m}^{\mathbf{3}}\right)\end{array}$ \\
\hline 1 & $\begin{array}{l}\text { Beton tanpa } \\
\text { campuran zat aditif }\end{array}$ & 5 & 2290,4 \\
2 & $\begin{array}{l}\text { Beton dengan zat } \\
\text { aditif dan kadar air } \\
0,4\end{array}$ & 4,5 & 2344,9 \\
3 & $\begin{array}{l}\text { Beton dengan zat } \\
\text { aditif dan kadar air } \\
0,5\end{array}$ & 5,5 & 2316,4 \\
& $\begin{array}{l}\text { Beton dengan zat } \\
\text { aditif dan kadar air } \\
0,6\end{array}$ & 6,5 & 2321,7 \\
\hline
\end{tabular}

Pada tabel 8, dapat dilihat bahwa hasil pengujian slump telah memenuhi slump rencana yaitu 30-60 mm, namun nilai slump untuk campuran dengan kadar air 0,6 dengan campuran zat aditif sedikit melebihi nilai slump rencana. Berat jenis $(\gamma)$ beton yang didapatkan mendekati nilai berat jenis $(\gamma)$ beton rencana $\left(2340 \mathrm{~kg} / \mathrm{m}^{3}\right)$.

\section{Hasil Pengujian Kuat Tekan Beton}

Pengujian kuat tekan beton yang dilakukan di laboratorium beton pada umur beton 7 hari dan 28 hari. Gambar 1 menunjukkan perbandingan nilai rata-rata kuat tekan beton dengan tambahan zat aditif Fosroc Conplast R 1\% dan Fosroc SP 337 $1 \%$ umur 7 hari dengan estimasi kuat tekan berdasarkan grafik SNI 03-2834-2000.

Grafik hasil uji kuat tekan beton pada umur 7 hari pada gambar 1 menunjukkan bahwa semakin tinggi kadar air yang digunakan, maka kuat tekan beton semakin rendah. Berdasarkan perbandingan hasil uji kuat beton dengan grafik kuat tekan beton rencana berdasarkan SNI 03-2834-2000 pada gambar 1, juga menunjukkan bahwa kuat tekan beton umur 7 hari dengan penambahan zar aditif Fosroc Conplast R 1\% dan Fosroc SP 337 1\% dengan variasi kadar air 0,4, 0,5 dan 0,6, terlihat bahwa kuat tekan yang didapat masih berada di atas garis estimasi kuat tekan umur 7 hari.

Gambar 2 menunjukkan perbandingan nilai rata-rata kuat tekan beton dengan tambahan zat aditif Fosroc Conplast R 1\% dan Fosroc SP 337 $1 \%$ umur 28 hari dengan estimasi kuat tekan berdasarkan grafik SNI 03-2834-2000.

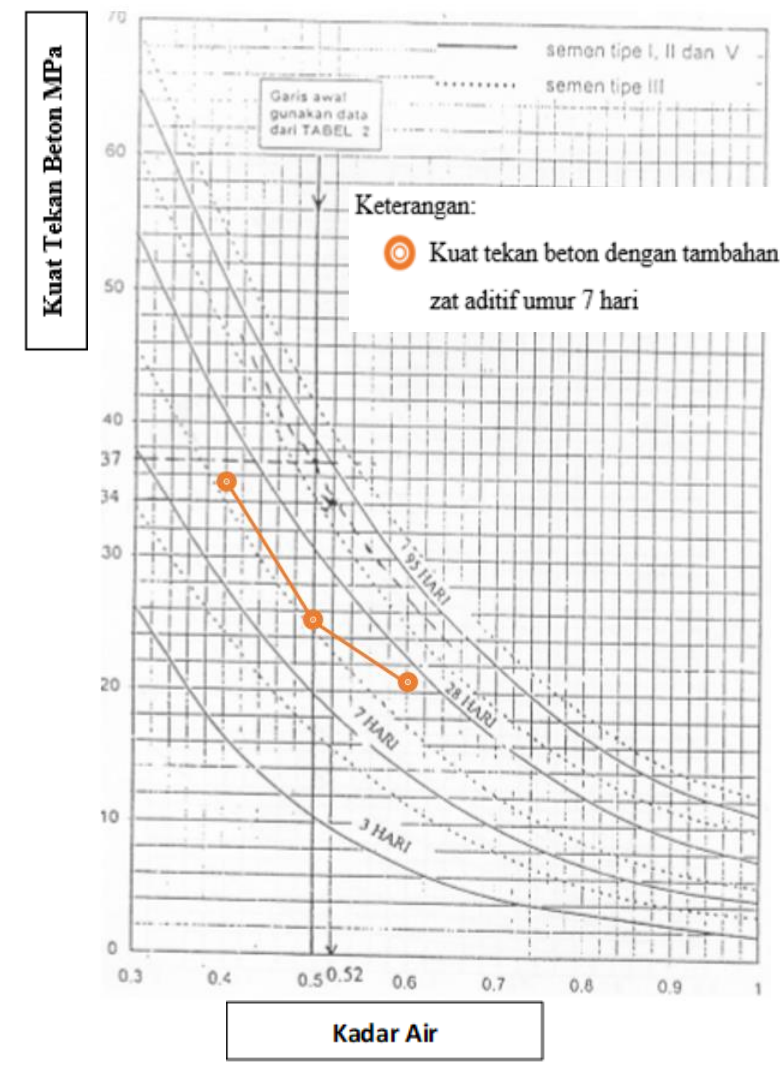

Gambar 1. Perbandingan nilai rata-rata kuat tekan beton umur 7 hari dengan grafik SNI 03-2834-2000

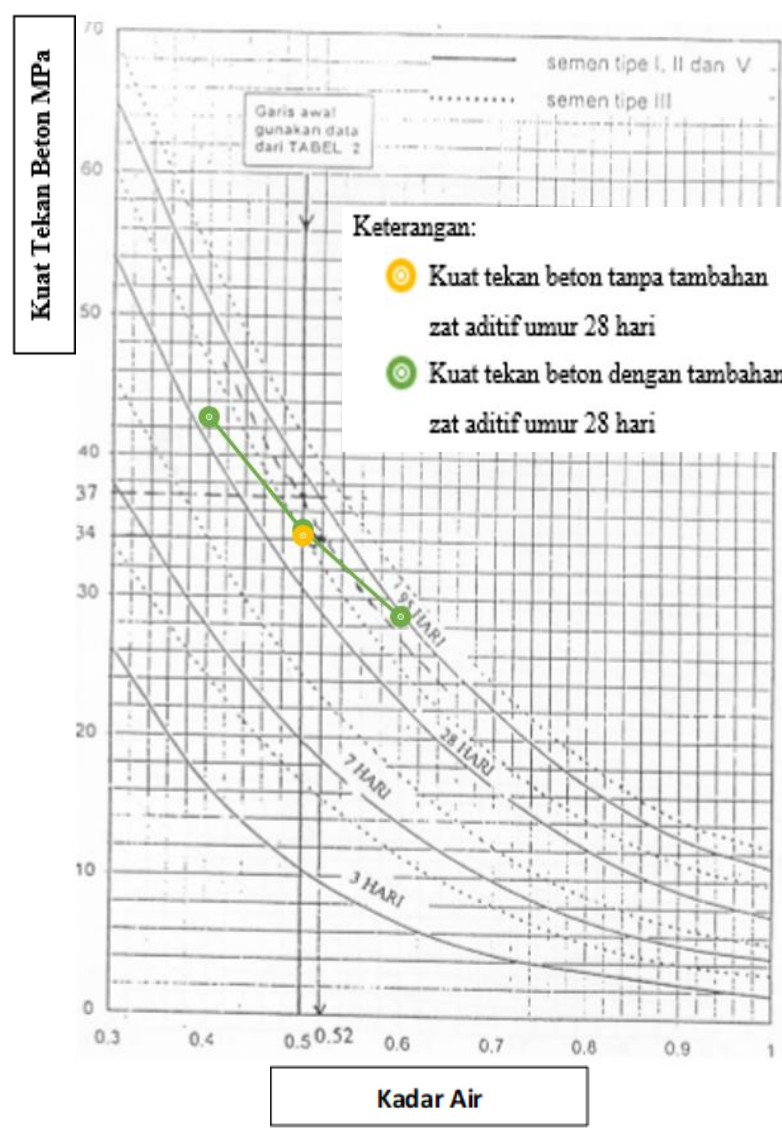

Gambar 2. Perbandingan nilai rata-rata kuat tekan 
beton umur 28 hari dengan grafik SNI 03-2834-2000

Grafik hasil uji kuat tekan beton pada umur 28 hari pada gambar 2 menunjukkan bahwa semakin tinggi kadar air yang digunakan, maka kuat tekan beton semakin rendah. Berdasarkan perbandingan hasil uji kuat beton dengan grafik kuat tekan beton rencana berdasarkan SNI 03-2834-2000 pada gambar 2, juga menunjukkan bahwa kuat tekan beton umur 28 hari tanpa penambahan zat aditif Fosroc Conplast R 1\% dan Fosroc SP 337 1\% maupun dengan penambahan zat aditif Fosroc Conplast R 1\% dan Fosroc SP 337 $1 \%$ dengan variasi kadar air 0,4, 0,5 dan 0,6 masih berada di atas garis estimasi kuat tekan umur 28 hari berdasarkan grafik estimasi SNI 03-2834-2000.

Dari hasil di atas, menunjukkan bahwa penambahan zat aditif Fosroc Conplast R 1\% dan Fosroc SP 337 1\% aman digunakan untuk memperpanjang waktu pengecoran beton di lapangan untuk beton dengan variasi kadair 0,4, 0,5 , dan 0,6 , karena hasil pengujian menunjukkan bahwa nilai kuat tekan rata-rata benda uji lebih tinggi dari kuat tekan rencana berdasarkan grafik SNI 03-2843-2000.

\section{KESIMPULAN}

Berdasarkan hasil penelitian dengan mengkaji pengaruh kadar air pada beton dengan penambahan zat aditif Fosroc Conplast R 1\% dan Fosroc SP 337 1\% terhadap nilai kuat tekan beton, maka dapat ditarik kesimpulan sebagai berikut:

1. Hasil pengujian kuat tekan beton dengan penambahan zat aditif Fosroc Conplast R 1\% dan Fosroc SP 337 1\% dan variasi kadar air 0,4, 0,5 dan 0,6, menunjukkan bahwa jika kadar air semakin tinggi, maka kuat tekan beton semakin rendah. Kuat tekan beton yang diperoleh pada umur 7 dan 28 hari lebih tinggi dari grafik kuat tekan rencana berdasarkan SNI 03-2834-2000.

2. Grafik hubungan kuat tekan dengan kadar air pada standar SNI 03-2834-2000 dapat digunakan untuk mengestimasi kuat tekan beton dengan variasi kadar air 0,4, 0,5 dan 0,6 dan penambahan zat aditif Fosroc Conplast R 1\% dan Fosroc SP 337 1\%, walaupun grafik tersebut merupakan grafik untuk kuat tekan beton tanpa tambahan zat aditif.

3. Beton dengan penambahan zat aditif Fosroc $\begin{array}{lllllll}\text { Conplast } & \text { R } 1 \% & \text { dan Fosroc SP } & 337 & 1 \%\end{array}$ menghasilkan kuat tekan beton yang lebih tinggi dari kuat tekan rencana untuk beton normal, sehingga zat aditif ini aman digunakan untuk memperpanjang waktu pengecoran beton di lapangan.

\section{DAFTAR PUSTAKA}

AASHTO T 27, (2014). Standard Method of Test for Sieve Analysis of Fine and Coarse Aggregates

A, Arman, Sonata, Herix, \& Ananda, Kartika, (2017). Studi Eksperimental Setting Time Beton Mutu Tinggi Menggunakan Zat Adiktif Fosroc SP 337 \& Fosroc Conplast R, Jurnal Momentum. 19 (2): 57-61

A, Arman. \& Ramayanti, Cici, (2018). Studi Eksperimental Metoda Pembuatan Beton Instan $F^{\prime} c^{\prime}=25 \mathrm{Mpa}$ dengan Penambahan Zat Adiktif Fosroc SP 337 \& Fosroc Conplast $R$, MENARA Ilmu. XII-I (79): 1-7

Asri, Rusman, \& Nisumanti, Sartika, (2014). Kuat Tekan Beton Mutu Tinggi dengan Penambahan Conplast SP 337, Jurnal Tekno Global. III (1): 14-20

Aulia, Fira Riza, Tjahjono, Elly, \& Arijoeni, Essy, (2015). Studi Pengaruh Penggunaan Agregat Halus Daur Ulang dan Agregat Kasar Daur Ulang dari Limbah Beton Padat dengan Mutu K350-K400 menggunakan Admixture Complast SP 337 terhadap Kuat Tekan, Kuat Lentur, dan Susut pada Beton, FT UI

PB-0206-76. Keausan Agregat dengan Mesin Los Angeles

SNI 1969:2008. Cara Uji Berat Jenis dan Penyerapan Air Agregat Kasar.

SNI 1970:2008. Cara Uji Berat Jenis dan Penyerapan Air Agregat Halus.

SNI 03-1968-1990 Metode Pengujian Tentang. Analisis Saringan Agregat Halus dan Kasar

SNI-03-2816-1992. Metode Pengujian Kotoran Organik dalam Pasir untuk Campuran Mortar atau Beton

SNI 03-2834-2000. Tata Cara Pembuatan Rencana Campuran Beton Normal, Badan Standar Nasional

SNI 03-4142-1996. Metode Pengujian Jumlah Bahan dalam Agregat yang Lolos Saringan No. 200 (0,075 MM)

SNI 03-4804-1998 Metode Pengujian Berat Isi dan Rongga udara dalam agregat 